DOI: https://doi.org/10.32839/2304-5809/2019-10-74-68

UDC 331.107

Zerkal Anastasiia

Classic Private University

\title{
THE IMPACT OF BUSINESS PARTNERS ON COMMERCIAL AWARENESS AND PERSONNEL MANAGEMENT OF ENTERPRISES
}

\begin{abstract}
Summary. Commercial awareness, as a resource, is beginning to replace physical assets of enterprises' for value creation in the marketplace. All too often business leaders don't see HR as having the commercial awareness to be real business partners. Due to competitive pressures, enterprises are now focusing on how to manage their awareness, just as they do the other resources that are used to produce their products and services. They see HR staff as fulfilling a purely transactional role - we're launching a new product, go and hire us the staff; we've completed our acquisition, now take care of profit. Business acumen and an ability to implement business strategy with an effective HR strategy are the skills most desired by business leaders of partners. If staff has hands on exposure to P\&L, financial processes, sales and marketing planning then not only do they develop their commercial skill set, but they build firsthand knowledge of the broader business agenda.
\end{abstract}

Keywords: commercial awareness, staff, enterprise, business, partners.

Зеркаль А.В. Класичний приватний університет

\section{ВПЛИВ ДІЛОВИХ ПАРТНЕРІВ НА КОМЕРЦІЙНУ СВІДОМІСТЬ ТА УПРАВЛІННЯ ПЕРСОНАЛОМ ПІДПРИЕМСТВ}

\begin{abstract}
Анотація. Комерційна свідомість, як складний нематеріальний ресурс, носієм якого є персонал підприємства, має значний вплив на фрізичні активи підприемств для створення додаткової вартості на ринку. Через значний конкурентний тиск підприемства зараз зосереджуються на тому, щоб керувати комерційною свідомістю персоналу, як і іншими матеріальними ресурсами, які використовуються для виробництва продукції та послуг. Особливості ринкових умов діяльності підприемства передбачають фрормування найбільш сприятливого для підприемства простору та потребують організації постійної взаємодії з діловими партнерами. Ефективне управління персоналом передбачає аналіз і прогнозування впливу навколишнього середовища на діяльність підприемства (в тому числі і персонал, зі сфрормованою комерційною свідомістю), своєчасне реагування на мінливі умови роботи підприємства. Зазвичай керівництво підприємств не усвідомлюе, що на комерційну свідомість та управління персоналом мають великий вплив контакти з діловими партнерами. Керівництво вважає, що персонал виконуе суто транзакційну роль - запускає новий продукт, займається виробництвом або дбайте про прибуток підприемства. Практика управління персоналом, така як підбір, навчання та розвиток, а також системи винагород, можуть бути, безумовно, важливими для управління комерційною свідомістю працівників на підприемствах. Правильне управління цим неповторним ресурсом (комерційною свідомістю) може забезпечити підприемству будь-якої галузі виробництва конкурентоспроможні переваги над своїми конкурентами з точки зору кращої системи управління персоналом. Комерційна свідомість та здатність реалізовувати бізнес-стратегію за допомогою ефрективної стратегії управління персоналом - це навички, які найбільше вражають бізнес-партнерів. Якщо персонал має вплив на наукові дослідження, фінансові процеси, планування продажів та маркетингу, то він не лише розвиває свою комерційну свідомість, а й отримує знання щодо ефективного ведення бізнесу. Управління персоналом пов'язане із комерційною свідомістю та грунтуеться на етичних принципах ведення бізнесу, моральних цінностях і соціальній відповідальності. Це передбачае відкритість, дотримання громадянської позиції, чесну конкуренцію та ефективну взаємодію із діловими партнерами.
\end{abstract}

Ключові слова: комерційна свідомість, персонал, підприемство, бізнес, партнери.

Tntroduction. The professionals to showing Lour commercial awareness you encounter will become some of your most useful contacts. They won't necessarily become clients but they can refer clients to you. The marketing jargon for a referrer is a "multiplier».

A good professional contact can lead to a stream of new clients throughout your career but such relations are usually built on a degree of reciprocity (referring clients back in return). This can prove awkward because your duty is to act in the best interests of your client and refer them to the professional best suited to help them, rather than the one who refers clients to you.

Research results. Organisational politics (which, as a professional, you need to recognise and work round) generally turns on relations between functions and competition between them.
At the top of the tree you find the CEO who is charged with day-to-day responsibility for any-and everything in the company. The company will also have a board of directors, of whom the CEO (often called Managing Director) is the most important. The board runs the company and is the executive (it executes the company's plans). There may also be a chairman of the board who is senior to the CEO or MD [1, p. 12].

The chairman may be an executive chairman but is often non-executive (part-time). The chairman tends to have an outward-facing, strategic and ambassadorial role. But it is the chairman who tends to be instrumental in getting rid of the CEO or MD if the latter isn't doing the job well. An executive director is employed in the business day-to-day.

A non-executive is part-time and is there in an advisory capacity. 
The functions most often represented at board level (executive directors) include:

Finance - this is the second most senior role at board level after CEO/MD, for obvious reasons.

Human Resources - in a knowledge economy, people are the most important asset (after money, according to Dilbert).

Marketing \& PR - responsible for external issues such as customers, brand, image and public relations.

Others include risk management (which may include legal, compliance and regulatory) to ensure the business is not going to be sunk by an unexpected exposure (legal may be represented separately). In a manufacturer, production may be represented along with $R \& D$ (research and development). In a know-how business, there may be a CIO (chief information officer). In an advertising agency, a creative director and so on. It depends on the particular industry. There may also be an IT director if systems are "mission critical». There may be a director of administration looking after premises, systems and so on. Increasingly companies have a COO (chief operating officer - a term which like CEO and CIO has come over from the US) who ensures the company is functioning smoothly and who is responsible for admin, systems, HR and some day-to-day financial management [1, p. 19].

The politics of organisations. Politics is almost a pejorative term ('He's playing politics») but in its original sense it just meant the affairs of the city ('polis' being Greek for "city»). Whenever you bring people together, in either a city or a company, you get politics - different views on what should be done and how.

In any organisation you find politics caused by functional frictions (different bits of a business that are thrown into conflict) which may lead to personal animosity. As a professional you need to recognise this and work around it. You need to get to know client organisations in enough detail to know where the power lies and where the political cracks and fissures are to be found.

Professionals can be exposed to organisational politics in two ways:

Who is the client? The client is the institution but who at the client are you taking instructions from? If it is more than one person, what happens if those instructions contradict each other?

What is the role of the professional? Clients often complain that external advisers tell them what they already knew anyway - so why are advisers brought in? Often the answer is politics: the only way to get an organisation to change - even though everyone inside knows what is required - is to bring in a third party to implement that change. So you need to think closely about what is going on under the surface; what are the "hidden agendas»; who's career is on the line; who can you really trust? [2, p. 64].

This is why you need to develop a wide network of contacts across a client organisation, so that you always know what is going on and so that if one contact is sidelined you have another to rely on. However, the fact is that, sooner or later, you and your firm may be out. A new broom may come in and decide to use another firm. Your contacts may be sidelined and leave. But don't worry: your old contacts will turn up in new jobs elsewhere and bring their new employer to you as a new client provided you stay in touch with them [3, p. 556].

As you get to know people in a client organisation, ask them about their roles and the particular challenges they face.

Ask yourself what a client organisation's service, product or purpose is. Look at the relevant trade publications (every industry has at least one newspaper or magazine devoted to it) and get a feel for the issues which that industry faces. If you start to specialise in a sector, go to the relevant industry conferences.

Doing these things will enhance your understanding of what your clients are doing and why, and the issues they encounter. You will be able to engage them in interesting conversations which will increase their respect for you.

One thing that irritates clients enormously is having a set of professional advisers who don't get on but who try to score points off each other, jockeying for position, trying to out-compete each other. To avoid this, you need to know what other professionals do.

Accountants get involved with companies in many different ways. All public companies are required to have annual audits and accountants act as auditors, compiling the information that goes into the annual report and accounts. In the biggest companies, teams of external auditors are at work almost the whole year round. But accountants get involved in other ways. They may be reporting accountants, overseeing the financials of a bid, for example. Smaller companies may use accountants for corporate finance advice, on the raising of money. At one point the major accounting practices had management consulting arms, but these were regarded as causing a conflict of interest (it's difficult to report objectively on a company's financial position while you are advising it on how to improve that position) [4].

Actuaries are statisticians who help pension funds work out what their future liabilities are likely to be and then advise them on how to manage their assets to generate a return to meet those liabilities. They do this by looking at the demographics of a group of people. So if, say, a pension fund has 4,000 retired workers and another 1,500 coming up to retirement in the next three years, the actuary can use information about that group (age profile, socio-economic mix, number of smokers, drinkers, those who have heart disease, etc) to work out the incidence of mortality - in other words, how many of them will, statistically, die when [5, p. 121]. Then the actuary can advise the pension fund on how much money it will be paying out to retired (but alive) workers and for how long. The pension fund then knows what investment return it needs to generate over, say, the next 5-10 years and can plan accordingly, hiring fund managers to deliver those returns.

Pensions used to be a boring backwater. No longer. People are living longer and are concerned about what they will live on. And companies have to account for future liabilities now, so they can't assume that future gains will fill any current funding gap. This means that the company (called the pension plan sponsor or scheme sponsor) must make up any shortfall. Pensions used to be based 
on your final salary - usually two-thirds of what you were earning when you retired - which was good because that was probably your maximum earnings level. These plans were called defined benefits (you knew what you were going to get). But they are expensive, especially if a company has to account on a present value basis. So many of these have been closed to new members and replaced by defined contributions schemes where you know how much you are required to put in but not what you will get at the end (that depends on investment returns in the meantime). Then, when you retire, the pot of money saved on your behalf is used to buy a contract (called an annuity because it pays out an annual amount, usually in monthly instalments) which supports you until you die [1, p. 96].

Aside from actuaries there are all sorts of consultants who advise pension funds, for instance on fund manager selection and monitoring, benchmarking of investment returns and so on.

Without advertising, most newspapers, TV and radio stations would fold. "Controlled publications" are distributed free and depend entirely on their advertising revenue; but all publications - even news-stand and subscription publications - rely on advertising for some of their revenue [6, p. 456]. Advertising ranges from billboards and adverts on the sides of buses to product placement in films. Despite the onslaught of new media, traditional advertising is still a huge business. Agencies advise clients on campaigns, do the design work and buy the space (an industry in itself). Large design agencies also have copywriters who write the words ("copy» here means a piece of text) [6, p. 457].

Bankers come in all shapes and sizes, but essentially divide between commercial bankers who lend money and investment bankers who arrange for the issue of shares and bonds. Bankers specialising in corporate finance advise on mergers and acquisitions and may also advise on the issue of shares (corporate finance is a traditional merchant banking activity now done by investment banks and to an extent commercial banks, especially when either is part of a conglomerate or bundled bank that does everything). Some possible areas of friction with bankers include:

1. They like to be seen to be driving the transaction forward so may treat other professional advisers as lackeys.

2. As a professional adviser, you may be advising the bank as opposed to the bank's corporate client - be sure which of the two is your client.

3. Even where you are advising the bank, the corporate may be paying your bill.

4 . The banker may only be paid on the successful completion of the transaction so if your advice is negative, this can annoy the banker [2, p. 87].

Brand specialists advise companies on image and brand and are often involved at a strategic level in helping to define a business and its markets and what it says about itself. More routinely they develop new logos. Traditional graphics design and advertising work has been subsumed within this and there are large agencies that encompass advertising, brand management, design and PR.

The term «broker» means intermediary. A commodity broker sells commodities («hard» ones include metals; "soft» ones are agricultural produce).
A futures broker sells futures (a contract to take delivery of a commodity or financial instrument in three months' time at a price agreed today). A stockbroker sells shares to retail investors. A corporate broker advises a company on share issues (and may be part of a bank). See the separate entry for «insurance brokers' [1, p. 46].

Engineers build things, everything from industrial robots to computers, from chemicals to aircraft. They build and install equipment. Civil engineers construct buildings, bridges, roads, ports and airports. Structural engineers worry about foundations. Marine engineers specialise in ships, electrical engineers in power, highway engineers in roads, and so on.

Fund managers - also known as asset managers, investment managers, money managers, portfolio managers, wealth managers - manage money on behalf of a company's pension fund. If a pension fund is big enough, it may have its own in-house fund managers, employed by the fund to invest its money. But most pension funds put at least some of their money out to external managers.

Those who invest equities (shares) specialise by: size of company (e.g. big cap - meaning large companies by capitalisation), investment style ("growth" - companies that don't produce much by way of dividend, «income» - companies that do, and "value» - companies whose shares are underpriced) [1, p. 142].

All of these are active managers, choosing investments based on analysis. But since pension funds measure the performance of their investments against the index (e.g. the FTSE 100), they are putting an increasing amount of their money into passive or index - tracking funds which simply match the index by investing in exactly the same shares as the index contains. Active managers strive to be upper quartile (in the top $25 \%$ of their universe of fund managers) but it's a zero-sum game (for everyone above average there is someone below average) with no guarantee that last year's top performer will be this year's. Which is why passive investment is increasingly popular, because it provides more consistent returns [2, p. 46].

Fund managers report on a quarterly basis to a pension fund's trustees. Those who persistently under-perform their benchmark index are sacked and replacements are suggested by the advisers to the fund (often actuaries or offshoots of them). Graphic designers A lot of people who study at art school go into industrial or applied design rather than fine art and end up doing everything from designing consumer packaging to creating brochures.

Insurance brokers act as intermediaries between insureds (companies) and insurers, helping companies buy insurance cover as cheaply as possible and advising on the sort of cover most appropriate. They also help with claims although large claims tend to be assessed by loss adjusters working for the insurer. Some big companies choose to "self insure" - in other words they bear any loss themselves on the basis that this works out more cheaply over the longer term because they keep the premium they would otherwise be paying. Insurers can be extremely large and international in their own right [2, p. 95].

ITC consultants Information, Technology and Communications is the ungainly term used to cover specialists in everything from telephony to com- 
puter systems. These people vary from individuals helping customers on specific ITC issues to large firms advising banks on the installation of vast risk management systems. People may be the ITC equivalent of a plumber, installing wiring in below- lloor ducts, to ITC strategists advising on the choice and installation of systems costing hundreds of millions.

Conclusions. The way round this is to give your client a choice of two or three professionals to choose from. Then it's up to your client to make his or her choice based on things like personal chemistry (so if the relationship doesn't work out it isn't your fault).

You should tell each professional that you have given the client their name but be sure to tell them that theirs isn't the only name you have given. This is the most they can expect from you. Equally in return, yours may not be the only name they give their clients - so it will be up to you to make a presentation or pitch to win the client based on your commercial awareness.

\section{References:}

1. Ambler, S.W., Nalbone, J., \& Vizdos, M. (2005). Enterprise Unified Process: Extending the Rational Unified Process. Prentice Hall, Englewood Cliffs, NJ: 364 p.

2. Cacciatori, E. (2006). Crafting Competencies for Strategic Renewal: the role of boundary objects. Bocconi Working Paper. Bocconi School of Management, Bocconi University, Milano, Italy: 218 p.

3. Carlile, P.R. (2004). "Transferring, Translating and Transforming: an integrative framework for managing knowledge across boundaries". Organization Science, 15 (5): 555-568.

4. Hoogervorst, J., Koopman, P.L., \& Van Der Flier, H. (2002). "Human Resource Strategy for the New ICT-Driven Business Context". International Journal of Human Resource Management, 13(8).

5. Sousa, P., Caetano, A., Vasconcelos, A., Pereira, C., \& Tribolet, J. (2006a). "Enterprise Architecture Modelling with the Unified Modelling Language 2.0", in P. Ritten (ed) Enterprise Modelling and Computing with UML. IRM Press, Hershey, PA: 121-123.

6. Sousa, P., Pereira, C., Vendeirinho, R., Caetano, A., \& Tribolet, J. (2006b). "Applying the Zachman Framework Dimensions to Support Business Process Modelling". Proceedings of the $3^{\text {rd }}$ International Conference on Digital Enterprise Technology, Setúbal, Portugal, 456-458. 